\title{
Analysis of Applied English Talent Training Mode of Local Colleges Based on Perspective of Market Talent Demand
}

\author{
Fang Yan \\ International College, Huanghuai University, Zhumadian 463000, China
}

Keywords: Market demand, Local colleges, Talent Training mode, Applied

\begin{abstract}
Influenced by current market demand, colleges in various places of China can finally complete optimized reform of talent training mode only through really regarding applied talent training as basic educational objective. Further, colleges can gradually enhance students' competitive capacity of job market, make students gain better development in social life and supply high-quality talents for society. This paper analyzes applied English talent training mode of local colleges based on market demand and hopes to offer certain support and reference for English education reform for local colleges.
\end{abstract}

\section{Introduction}

As the trend of world economy integration continues to strengthen, communication and interaction between China and world economy system also increase. This brings new development opportunity for graduates majoring in Business English to some extent. Meanwhile, it is found through investigating relevant foreign trade corporations that, such enterprises greatly demand practical English talents. Thus, according to English teaching English teaching syllabus issued by the Ministry of Education in the new period, English discipline should focus on training interdisciplinary practical English talents to make every graduate independently complete various tasks in related commercial activities. In current society where science, technology, economy and culture gain rapid development, how to explore training mode of applied English talents according to market demand has become a key content of English education reform of colleges in various places, and it receives great attention from English education major of colleges in various places.

\section{Current actual demand of Chinese talent market for professional English talents}

As China and world economy contact more and more frequently in the $21^{\text {st }}$ century, cross-border mergers, acquisitions and overseas listing Chinese international trade enterprises participate in as well as overseas investment attraction activities of local governments become increasingly frequent, which to some extent makes market demand of interdisciplinary English talents with intercultural communication competence rise increasingly and promotes new development of English education ${ }^{[1]}$. In particular, when China officially joined WTO, China's national power has become gradually national power. China succeeded in holding Olympic Games in 2008 and then also successfully held Shanghai World Expo and Xi'an International Horticultural Exposition. These bring huge talent market effect and offer very expansive employment platform and development prospect for English talents of colleges in various places. Seeing from current prosperous economic development trend, China's economic society will certainly keep the demand for interdisciplinary English talents in a long time, so colleges in various places should regard market demand as the basic orientation in talent market, deem training of interdisciplinary English talents as education mission, reform traditional education mode, improve teaching effectiveness and cultivate a group of high-quality applied English talents for the society. 


\section{Construction of applied English talent training mode for local colleges based on market demand}

\section{Change educational concept and reform teaching method and basic education mode}

It can be seen from current market demand for talents that, Chinese traditional local colleges have certain defects in English teaching mode. Talent training pays more attention to knowledge reserve, but neglects improvement of comprehensive quality and cultivation of knowledge application ability. Thus, such teaching mode cannot adapt actual needs of current economic and social development. Traditional English talent training of local colleges takes English language learning as main teaching content. In essence, it pays excessive attention to scope of English knowledge, but neglects teaching of English skills. This leads to students' poor English application ability. Even if students are employed smoothly after their graduation, they cannot obtain the affirmation of employers ${ }^{[2]}$. Meanwhile, traditional English education mode pays insufficient attention to training students' basic English communication ability and has certain defects in document writing education and special education related to economy and trade. This goes against students' all-round development. Thus, to enhance practicability of talent training for English education major, it is required to transform educational concept, select scientific teaching method and construct more suitable education mode, such as replacing traditional cramming teaching with heuristic and inquiry-based teaching, and change from closed teacher's teaching to interactive teaching. Only in this way, English learning enthusiasm and initiative of teachers and students can be really motivated to create conditions for cultivating students to become talents needed by the society.

\section{Get rid of traditional constraints and innovate for talent training mode}

Colleges in various places of China generally choose the training mode of combining English teaching with major development direction to carry out English teaching. But, as integration of world economy strengthens and China's social economy develops deeply, new changes happen to the demand of economy and trade fields for professional English talents. Seeing from transverse contrast, current English major education in China presents the development trend of sailing in the head tide. Some disciplines closely related to English major education, such as international trade and international relation majors start to perfect and innovate for talent training mode in order to adapt social development. Once the innovation of professional talent training mode develop maturely, obsolete and behindhand English talent training mode cannot adapt the need of synchronous development and encounters development difficulties ${ }^{[3]}$. Hence, local colleges must carry out scientific innovation of talent training mode in the new period, actively explore training methods of interdisciplinary and applied talents. In terms of specific operation, colleges in various places may adopt the talent training mode which pays equal attention to English and major, actively explore joint school running of social enterprises and sending students in English-speaking countries for exchange, further expand students' view, enhance students' post experience and lay a foundation for cultivating students to become talents meeting social needs.

\section{Construct scientific CBE education and teaching mode}

Aiming at the problems existing in English education of colleges in various places, colleges may combine development situations to construct CBE fundamental education mode in order to solve shortcomings in traditional education mode. Simply speaking, CBE fundamental education mode takes professional skills and comprehensive quality as the main task. In other words, talent training should be oriented to market demand and deem cultivation of students' various basic skills and comprehensive quality needed in social employment as the objective ${ }^{[4]}$. Applied English talent training mode based on market demand should specify all kinds of comprehensive qualities and professional abilities which should be owned by applied talents needed by the market, carry out various education activities as the basic orientation according to market demand, set up corresponding talent training objective, position talent training work and then carry out scientific planning of curriculum system, education practice link and teaching contents. Only in this way, English talents cultivated by colleges in various places can own high-level business working ability, meet market demand and make corresponding contributions to further development of economic society. 


\section{Basic measures to construct applied English talent training mode}

\section{Fulfill basic objective of talent training and optimize curriculum system setting}

Setting teaching for English major aims to cultivate the students to become interdisciplinary talents who own rich English knowledge reserve, solid professional foundation, excellent English application ability and high-level intercultural communication competence, and can master certain knowledge of economics, management and laws and solve practical problems with English in international business environment. But, there is actually a huge gap between English talent training and the education objective. To some extent, this causes students' psychological enduring capacity and social adaptation ability are low when students participate in social work after their graduation, and they cannot be qualified for their work. These impose serious impacts on future development. Therefore, colleges in various places must reform and optimize traditional and behindhand classroom system in order to make sure talent training objective is implemented in education practice. It is required to combine enterprises' practical talent demand and basic suggestions on curriculum setting and regard cultivation of students' correct working view and establishment of social values as key teaching contents, properly penetrate career planning education concept and make students correctly position themselves and specify future development direction through systematical learning. In addition, influenced by major nature of English, enhancement of language knowledge skills and English expression ability is crucial to cultivation of applied English talents. Thus, colleges in various places should strengthen attention to basic language skill training in teaching practice and lay $\mathrm{s}$ foundation for training applied English talents through scientific curriculum system setting.

\section{Enhance faculty training and boost professional quality of teaching team}

Teachers are the leaders of all teaching activities. Teachers' teaching level plays a decisive role for teaching quality. Hence, construction of scientific teaching mode must deem teaching team building as the key work and corresponding human resource guarantee is provided for applied English talent training mode through high-quality teaching team. In specific English teaching practice, students generally greatly expect teachers; teaching ability. In the view of students, qualified professional English teachers should not just master English knowledge and skills, but also should own certain business knowledge and trade knowledge so as to meet students' learning demand for English knowledge $^{[5]}$. But, current teachers of English major generally lack economic knowledge, which is adverse to applied English talent training. Therefore, colleges in various places should take certain measures, organize teachers of English major to participate in advanced studies, enhance teachers' professional skills, provide teachers with corresponding enterprise practice opportunity, let English teachers personally participate in relevant international economic cooperation, know practical use of business English and then promote teachers' integrated development and offer certain faculty support for creation of applied talent training mode.

\section{Compile teaching materials again and perfect construction of teaching material system}

Construction of teaching material system is the core of various curriculum activities and generates important influence on creation of talent training mode. Scientific and reasonable teaching material system certainly has certain pertinence and hierarchy, and can guide teachers to carry out teaching work progressively and offer corresponding guarantee for stabilizing teaching order and further improving teaching quality. Hence, colleges should regard selection and compiling of teaching materials of English major as the important link of creating talent training mode. Relevant survey shows in current stage, most teachers and students in China are dissatisfied with English teaching materials in economic aspect and consider contents of teaching materials are obsolete and lack corresponding interaction link with strong theoretical property, low interestingness and poor practicability. Hence, it is very difficult to mobilize students' learning initiative in practical application process, which generates adverse influence on learning effects. On this basis, selection and compiling of new teaching materials should regard interactivity, interestingness and practicability as the basic principle, and rationally control the proportion of contents of original English edition and Chinese-English bilingual teaching contents so that students can boost pureness of English language, enhance practical application ability and lay a foundation for future development through deep-level learning of original English teaching materials. 


\section{Carry out university-enterprise cooperation and offer practice platform for students}

Studying something in order to apply it has been important thought of China's education field, and generates far-reaching influence on education and teaching of different disciplines in different stages. English teaching in local colleges should also practice this thought, be devoted to training students to talents needed by society, promote personal development and make corresponding contributions to social development. In current stage, large transnational enterprises in China tend to use "sandwich" recruitment mode, i.e. the upper and lower layers are students' professional skills and comprehensive qualities, but the core of "sandwich" is students' internship experience before their graduation. The survey research on college graduates shows that social mainstream enterprises pay attention to students' internship experience and practice ability in recruitment process and attach importance to students' comprehensive qualities. Hence, colleges should enhance university-enterprise cooperation during creating English teaching mode. On the one hand, enterprise experts should be invited to carry out relevant knowledge lecture in colleges to enhance students' cognition of the major and practical application knowledge; on the other hand, colleges may organize students to participate in relevant practical activities in enterprises, and personally experience practical application of English knowledge in commercial activities so that students can strengthen their knowledge application ability in practical problem solving ability and gradually develop to applied English talents and lay a foundation for future development.

\section{Conclusions}

As China's economic environment, financial environment and investment environment become increasingly stable after China joined WTO, Chinese society pays more attention to enhancing knowledge application ability of English talents and hopes to train English talents to interdisciplinary talents with English competence and business ability. Therefore, colleges in various places should give full play to education advantages, combine market demand to construct scientific and reasonable talent training mode, keep up with the pace of times, gradually improve graduates' knowledge application ability, lay a foundation for students' future development and make corresponding contributions to national economic development and socialist modernization construction.

\section{Acknowledgments}

This paper is a phased achievement of 2013 Henan soft science project "Study on interdisciplinary applied English talent training mechanism under background of strategic emerging industry” (No.: 132400411214).

\section{References}

[1] Huang Kaidi, Xu Huayan, Pan Yajun et al., Career goal of English majors and English talent market demand. Examination Weekly, 2012(24):83-84.

[2] Yang Haiying, Study on demand of Hengshui City for vocational business English talents. Huazhang, 2014(18):261-261.

[3] Cai Chenglong, Pan Baojian, Training applied English talents under task-based teaching mode. Journal of Hechi University, 2013,33(3):61-63.

[4] Song Yuhua, Yang Xiao, Demand for Business English talents. Asia-Pacific Journal of Education, 2015(22):170-170,164.

[5] Li Pengpeng, Cui Jianwei, Li Hui et al., Exploration of applied English talents and specialized course design orientation. Modern Rural Science and Technology, 2013(18):70-71. 